\title{
Chemical Composition of Industrial Effluents and Their Effect on the Survival of Fish and Eutrophication of Lake Hawassa, Southern Ethiopia
}

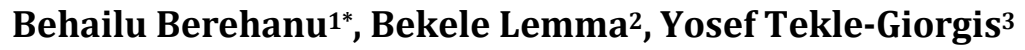 \\ ${ }^{1}$ School of Earth Sciences and Engineering, Addis Ababa Science and Technology University, \\ Addis Ababa, Ethiopia \\ ${ }^{2}$ Department of Chemistry, Hawassa University, Hawassa, Ethiopia \\ ${ }^{3}$ School of Animal and Range Sciences, Hawassa University, Hawassa, Ethiopia \\ Email: *behailu.berehanu@gmail.com
}

Received 4 May 2015; accepted 7 August 2015; published 10 August 2015

Copyright (C) 2015 by authors and Scientific Research Publishing Inc.

This work is licensed under the Creative Commons Attribution International License (CC BY). http://creativecommons.org/licenses/by/4.0/

(c) (i) Open Access

\section{Abstract}

Growing trends in industrialization in Ethiopia have raised concerns about pollution of water bodies particularly of lakes. This study was therefore conducted to 1) characterize the chemical contents of major industrial effluents (namely textile ceramic and soft drink factories) that reached Lake Hawassa and 2) investigate the effects of the above mentioned factory effluents on survival of larvae fish and growth of algae. Effluent samples were collected from the outlet lagoons of each factory in December, 2009. Then, effluent samples were analyzed for total $\mathrm{N}, \mathrm{NO}_{3}-\mathrm{N} \mathrm{NH}_{4}-\mathrm{N}, \mathrm{S}^{2-}$, $\mathrm{SO}_{4}^{2-}, \mathrm{PO}_{4}^{3-}, \mathrm{COD}$, total dissolved solids (TDS) and heavy metals at the federal Environmental Protection Agency (EPA) Laboratory, Addis Ababa. The experiments on the impact of effluents on survival of fish larvae and growth of algae were conducted using six concrete paved ponds (with different concentration of effluent). The results of chemical analysis showed that textile effluent had high COD (nearly 3 times higher), TDS (19 times higher) as well as $\mathrm{PO}_{4}^{3-}$ (39 times higher) than the maximum permissible limits (MPL) set by Environmental Protection Authority (EPA). Among heavy metals, $\mathrm{Zn}$ and Fe of textile effluent were much higher (41 and 1.5 times higher, respectively) than the MPL set by EPA. Ceramic effluent also contained high concentration of $\mathbf{P O}_{4}^{3-}$ (24.5 times), $\mathrm{S}^{2-}, \mathrm{SO}_{4}^{2-}(2$ times) and $\mathrm{Zn}(14$ times) exceeding the limit of EPA. Regarding soft drink factory, high values of $\mathrm{COD}, \mathrm{PO}_{4}^{3-}$ and $\mathrm{Zn}$ were found in the effluent than the limit specified

\footnotetext{
${ }^{*}$ Corresponding author.

How to cite this paper: Berehanu, B., Lemma, B. and Tekle-Giorgis, Y. (2015) Chemical Composition of Industrial Effluents and Their Effect on the Survival of Fish and Eutrophication of Lake Hawassa, Southern Ethiopia. Journal of Environmental Protection, 6, 792-803. http://dx.doi.org/10.4236/jep.2015.68072
} 
by EPA. The biological treatment lagoons of the respective source were not effective since the effluents were taken from the last treatment lagoon (outlet lagoon) and some of the measured parameters were higher than MPL. Results of the pond experiment showed that $5 \%, 10 \%$ and $20 \%$ concentration levels of the HTF effluent killed significantly high proportion of the fry $(65 \%, 86.8 \%$ and $88.7 \%$, respectively). In contrast, fry mortality in ceramic and soft drink effluent treatments, even at 10 and $20 \%$ concentration levels, stayed nearly below $10 \%$, which were not far off from the mortality of the control groups. Algal biomass in the treated ponds varied with the type of effluent treatment and concentration level. Compared with the first day, chlorophyll "a" concentration measured on the $7^{\text {th }}$ day had increased by $51 \%, 48 \%, 74 \%, 27 \%$ and $31 \%$ at $0 \%, 1 \%, 5 \%, 10 \%$ and $20 \%$ concentrations, respectively of textile effluent. The $5 \%$ treatment level of textile effluent caused the highest rate of algal growth above the growth rate observed in the control pond, but further increased in concentration to $10 \%$ and $20 \%$ resulted in a lower growth of algae than in the control pond. Therefore, textile effluent may boost up algae growth at lower concentrations $(\sim 5 \%)$ but at higher concentration levels its toxic effect may become inhibitory. Regarding the effluent of soft drink factory, algal growth progressively diminished with increasing concentration of the effluent. The overall change (between initial and day 7) in chlorophyll "a" concentration was highest in the control pond $(36.2 \%)$ and decreased with increasing effluent concentration (1\% to $20 \%)$ from $\mathbf{2 1 . 7 \%}$ to $\mathbf{- 9 . 4 \%}$. On the other hand, algal growth under ceramic effluent treatment was comparable with that observed in the control pond.

\section{Keywords}

\section{Lake Hawassa, Industrial Effluent, Fry Mortality, Chlorophyll “a”, Algal Growth, Eutrophication}

\section{Introduction}

Lake Hawassa is one of the eight major lakes found in the Ethiopian rift valley. The importance of this Lake is indispensable. The lake supports different species of phytoplankton, zooplankton, bacterioplankton and of fishes of which three are endemic and commercially important (Tudorancea et al., 1989 [1]; Mengistu and Fernando, 1991a [2]; Kebede, 1987 [3]). Different species of waterfowl, hippopotamus and reptiles also reside in and supported by the lake. The lake supports more than hundreds of bird species including resident and Palaearctic migrants. The community of Hawassa and its environs utilize the resources of the lake as a livelihood source for a very long time. It is an important source of water for the surrounding rural population for various domestic uses and livestock, as well as to irrigate their crops (personal observation). The fishery of the lake supplies vital fish protein and incomes for the extremely poor women and children of the area and beyond.

The lake has been facing serious ecological problems due to deleterious anthropogenic activities in the catchment. Intensive deforestation, animal grazing and traditional farming have reduced the vegetation cover and enhanced the soil erosion in the basin (Dessie and Kleman, 2007 [4]). Runoff from street surfaces contaminated with various pollutants is unregulated and discharged directly into the lake. Since the past few years, anthropogenic pollution of the lake has become a serious concern because of the building of different factories, floriculture and hospital in Hawassa. Studies indicate possible contamination of the lake water. Toxic heavy metals identified in the effluent of textile factory include $\mathrm{As}, \mathrm{Cr}, \mathrm{Cu}, \mathrm{Hg}$, and $\mathrm{Pb}$ that are poisonous for human and aquatic life (Zinabu and Desta, 2002 [5]).

Lake Hawassa is bounded by volcanic hills and mountains which are more or less impermeable (Ayenew, 2007 [6]) and water flow converges towards Lake Hawassa from almost all sides. Hence, the surface and subsurface drainage is towards the lake. Therefore, the lake is the main destination for any type of contaminants generated from urban activity and the caldera rim.

Different studies have been carried out on different aspects on Lake Hawassa. Kebede and Belay (1994) [7] studied the species composition and phytoplankton biomass in Lake Hawassa. Zinabu et al. (2003) [8] studied the heavy metal concentration of the lake and the textile factory effluents. Zinabu (2002) [9] examined the effect of wet and dry seasons on major solutes of the lake water. Ataro et al. (2003) [10] investigated heavy metal concentration of some fish species in the lake and determined the Hg concentration in fish species of the lake in 
relation to their diet. But these studies didn’t address what level effluent could be detrimental to biota if effluents continued to mix with the lake water. This study was therefore conducted to 1) characterize the chemical contents of industrial effluents (namely textile, ceramic and soft drink factories) that reached Lake Hawassa and to compare the level of chemical contents to the maximum permissible level (MPL); 2) envisage what would happen if the effluents were directly disposed in the lake, by setting up an experiment in a series of concrete paved ponds to investigate the impact of effluents of the above mentioned sources on survival of the lake fish and eutrophication of the lake.

\section{Methodology}

\subsection{Study Site}

Lake Hawassa is found at the eastern shore of Hawassa city, the capital of SNNPR state, which is located about $275 \mathrm{~km}$ south of Addis Ababa. The lake is geographically located between $6^{\circ} 33^{\prime} \mathrm{N}-7^{\circ} 33^{\prime} \mathrm{N}$ and $38^{\circ} 22^{\prime} \mathrm{E}-$ $38^{\circ} 29^{\prime} \mathrm{E}$ at an altitude of $1680 \mathrm{~m}$ a.s.l (Figure 1). The lake is the smallest of the eight rift valley lakes in Ethiopia with an area of $90 \mathrm{~km}^{2}$. It has a maximum length of $17 \mathrm{~km}$, a mean width of $6 \mathrm{~km}$, a maximum and mean depth of 21 and $11 \mathrm{~m}$, respectively. The mean minimum precipitation of the Hawassa area is $17.8 \mathrm{~mm}$ in December (dry season) and the mean maximum precipitation is $119.8 \mathrm{~mm}$ in August (rainy season).The mean annual precipitation is about $955 \mathrm{~mm}$. The temperature of the region varies between $12^{\circ} \mathrm{C}$ in the rainy season and $27^{\circ} \mathrm{C}$ in the dry season and the mean daily temperature is $18.9^{\circ} \mathrm{C}$.

The limnology and plankton of Lake Hawassa have been studied by several authors. The predominant ions in the lake water are sodium and bicarbonates and the lake is freshwater with a mean conductivity of $850 \mu \mathrm{S} \cdot \mathrm{cm}^{-1}$ (Talling and Driver, 1963 [11]). The major taxa of phytoplankton in the lake are Botryococcus braunii, Microcystis spp. and Lygnbbyanyassa (Kebede, 1996). The dominant group of zooplankton includes cyclopoid copepods (Mesocyclops aequatorialis similis and Thermocyclops consimilis) and Cladocera (Diaphanosoma excisum) (Mengistu and Fernando, 1991a). Benthic diatoms (such as Synedra, Cymbella, Nedium and Gomphonema), Ostracods, Chironomids and other insect larvae constitute the benthic community (Tudorancea et al., 1988).

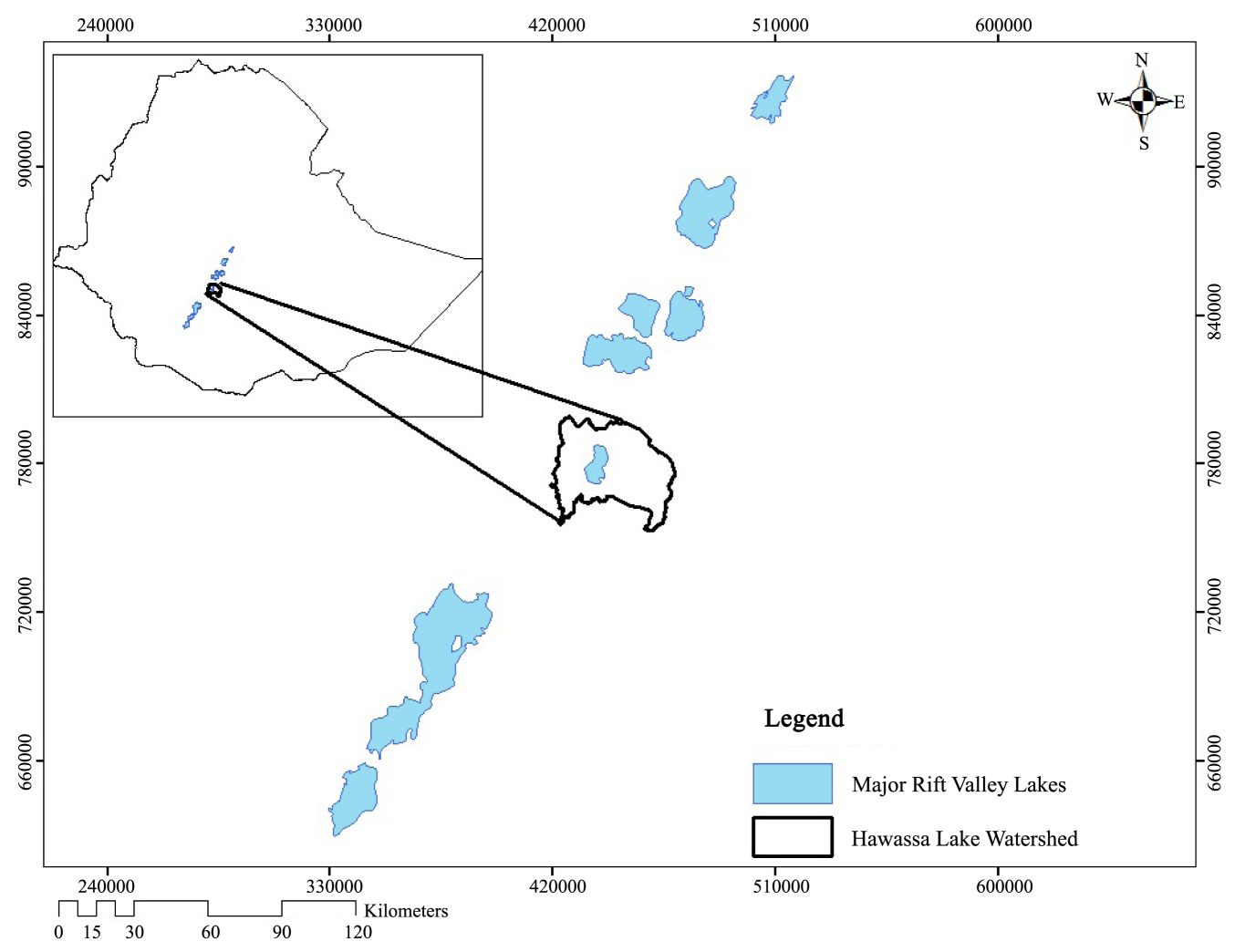

Figure 1. Lake Hawassa catchment in relation to the other major rift valley lakes of Ethiopia. 
There are six fish species in Lake Hawassa amongst of which three are commercially important namely the Nile Tilapia (Orechromis niloticus), the African sharptooth catfish (Clarias gariepinus), and the big Barb (Labeobarbus intermedius). The three minnow fish that are not fished due to their small size are Barbus paludinosis, Garaquadrimaculata and Aplocheilichthysantinorii. The commercial fishery mainly rests on tilapia that accounts to over $85 \%$ by weight to the total annual landings followed by catfish $(14 \%)$ and the big barb $(<1 \%)$. Gillnetting is the major method used by the commercial fishery although long lines are used to catch catfish. The annual fish landing ranges between 450 and 600 t/year (Yosef, 2002 [12]).

In Hawassa city, there are different factories amongst of which the big ones are textile, ceramic and soft drinks factories. Effluents released from the textile and soft drink factories move through the surrounding farmland and eventually enter a swamp, which is the source of Tikur Wuha River that ends up in Lake Hawassa. The effluents of ceramic factory is directly disposed into the lake (Personal observation). Effluents of textile and soft drink factories are treated chemically with sulphuric acid and biologically in a lagoon before disposal. Tabor Ceramic Factory discharges its effluent after treating it in a biological lagoon.

\subsection{Effluent Sampling and Analysis}

Effluent samples were collected in three replicates at the outlet lagoons or immediately after release in December, 2009. The samples were collected in plastic containers which were cleaned and socked in $10 \% \mathrm{HNO}_{3}$ for 24 hrs and rinsed with de-ionized water. Effluent samples were then filtered through what man GF/C filter papers and were then analyzed for heavy metals at the federal Environmental protection Agency Laboratory, Addis Ababa using Perkin Elmer Analyst 800 atomic absorption spectrophotometer (Buck Scientific Model 210 VGP, USA) according to standard methods.

Chemical oxygen demand (COD), Total nitrogen, $\mathrm{NO}_{3}-\mathrm{N}, \mathrm{NH}_{4}-\mathrm{N}$, Sulphide, Sulphate and phosphate of effluent samples were measured using spectrophotometer (DR/2010 HACH, Loveland, USA). Total dissolved solids (TDS) and conductivity of the effluents was measured using conductivity meter (CO 150, USA).

\subsection{Fish Survival Experiment}

\subsubsection{Pond Preparation and Stocking of Fish}

Five different concentration levels of textile, ceramic and soft drink factory effluents (i.e., $0 \%$ (control), $1 \%$, $5 \%$, $10 \%$ and $20 \%$ ) were tried on tilapia fry sampled from the lake and grown in experimental ponds containing lake water. The experiments were conducted using six ponds (one for each concentration trial and a reserve pond) found in Hawassa College of Agriculture campus fishery experimental site. The ponds were concrete paved and each had a dimension of $2 \mathrm{~m} \times 1.5 \mathrm{~m} \times 1.2 \mathrm{~m}(\mathrm{~L} \times \mathrm{W} \times \mathrm{D})$. The ponds were filled with freshly pumped lake water to one meter depth, and thus the effective volume of each pond used for the experiment was $3 \mathrm{~m}^{3}$. After filling, the ponds were awaited for two days before stocking fish and in the meantime some water quality parameters (oxygen content, $\mathrm{pH}$ and conductivity of the pond water) were measured three times daily (8 AM, $12 \mathrm{PM}$ and 5 PM) to check if they were within the normal range for the fish.

Tilapia fry (measuring 4 to $6 \mathrm{~cm}$ in total length) were caught from the shore of the lake with a beach seine net and were transported to the pond site in barrels (200 liters capacity) containing lake water. Fryused for the different factory effluent trial experiments were similar in size and were caught from the same location (eastern shore, "Amora-Gedel" area). During transportation, the water in the barrels was frequently cooled by adding ice in order to lessen the risk of oxygen stress due to warming up of the water. Ten fish were stocked at a time into each pond until the required number of fish was stocked per pond. Since fish stocked into the ponds shortly after arrival were less stressed and robust than those awaited in the barrels for some time, following the above stocking procedure allowed stocking of fish of similar conditions in the different ponds. Usually stocking of fish was terminated after 30 to 40 minutes in order to avoid stocking of stressed fish. Slightly more than 100 fry (110 to 130) were stocked in each pond and this gave reasonably good number of surviving fish for the treatments after the acclimation period.

\subsubsection{Acclimation of Fish, Effluent Treatment and Collection of Relevant Data}

Freshly stocked fish were given six days of acclimation period to let the stressed fish die out and the survivors regain their strength and adapt to the pond condition before treatment. Most of the stressed fish died within 24 hrs after stocking and death rate drastically declined during the second and third days post stocking period. 
About $10 \%-15 \%$ of the stocked fish died during the acclimation period and around 100 fry survived in each pond for the experiment. Died fish were spotted floating at the surface of the water and were removed constantly (every 2 to 3 hrs.). In most of the trials, fish death stopped starting the fourth day of acclimation period. But the fish were awaited for two more days after complete stoppage of death so as to give survivors sufficient recovery and adaptation time. Thus, effluent treatments were commenced six day after stocking. Also during the acclimation period, water quality parameters $\left(\mathrm{O}_{2}, \mathrm{pH}\right.$ and conductivity) were recorded three times daily to ensure suitability of the pond water for the fish.

Since the final volume of each pond was $3 \mathrm{~m}^{3}, 30,150,300$ and 600 liters of the respective factory effluent was added to make up $1 \%, 5 \%, 10 \%$ and $20 \%$ concentrations. Thus a total of 1080 liters of effluent was collected from the last (outlet) lagoon of the respective factory and was transported to the pond site in clean plastic barrel. Data on fish mortality were collected three times daily for 7 days of treatment period. Based on this, mortality rate was calculated as percentage of fish died out of the treated fish (survivors after acclimation period) and the latter was used to compare the effects of the three factory effluents and concentration levels on fry survival.

\subsubsection{Experiments on Algae Growth}

The growth of algae in effluent treated lake water was studied by taking water samples from each pond and determining the chlorophyll "a" concentration of the samples. During each effluent trial, about $500 \mathrm{ml}$ of water sample was taken from each of the five treatment ponds $(0 \%, 1 \%, 5 \%, 10 \%$ and $20 \%)$ three times during the course of the seven days experimental period i.e., on the first day (right after treating the ponds with effluent), $3^{\text {rd }}$ day and $7^{\text {th }}$ day of the experiment. Thus a total of 15 water samples were taken during each effluent trial, making up a total of 45 water samples from the three effluent trials. $100 \mathrm{ml}$ of water sample was filtered using Whatman GF/C glass fiber filter. Triplicate water samples were filtered for a given effluent concentration trial and 15 filtrations were completed for the five concentration trials of the respective effluent type. After extracting the filtrate with acetone, spectrophotometeric reading of the filtrate was recorded to estimate chlorophyll "a" concentration. The formula of Talling and Driver (1963) was employed to calculate the chlorophyll "a" concentration $(\mu \mathrm{g} / \mathrm{l})$ of the sampled water.

\section{Results and Discussion}

\subsection{Effluent Composition}

\subsubsection{Effluent of Textile Factory}

Hawassa textile factory is relatively the most studied industrial effluent, and the effluent was analyzed by different researchers in different periods of time (Table 1 and Table 2). Relatively low chemical oxygen demand (COD), low concentration of nitrate, total $\mathrm{N}(\mathrm{TN})$, sulphide, sulphate $\left(\mathrm{SO}_{4}^{2-}\right)$ and total dissolved solids (TDS) were detected in the effluent in the present study as compared to one or more of the previous studies (Table 1). By contrast, higher concentration of phosphate and electrical conductivity (EC) were measured as compared to Abay (2007) [13]. Results showed considerable differences among different investigations (Table 1). Water is mainly used as a solvent for processing chemicals and it is also a washing rinsing medium and the textile factory discharges about $1200 \mathrm{~m}^{3}$ of liquid waste every day (Zerihun, 1997) [14]. The wastewater from wet processing (which consists of the processing chemicals used and any other impurities extracted from the textile materials) is discharged into the effluents. Wastewater varies greatly in composition depending on the process used (Alemayehu, 2008) [15], wastewater management and amount of water used in the production (Pala, 2001) [16].

Textile effluents are known to contain complex mixtures of chemicals that vary in composition from factory to factory as well as from time to time based on materials used during wet processing (Wynne et al., 2001) [17]. In general, in the result of this study, high COD (nearly 3 times higher), TDS (19 times higher) as well as $\mathrm{PO}_{4}^{3-}$ (39 times higher) were found in textile effluent compared to the maximum permissible limit (MPL) set by EPA (2003).The effluent is mostly loaded with colors (20.0 platinum cobalt standard) from the coloring process in the factory. There are large varieties of dyes used in textile factories in an attempt to make more attractive popular shades of fabrics (Mathur et al., 2005) [18]. Therefore, it is likely that polluting organic molecules could be present in the effluents since studies have shown that some dye groups, mainly azo dyes and their by-products can be carcinogenic and/or mutagenic (Yusuff and Sonibare, 2004) [19]. 
Table 1. Mean values of chemical parameters in textile effluent reported by various researches in relation to the maximum permissible limit prior to discharge to the environment.

\begin{tabular}{|c|c|c|c|c|c|}
\hline \multirow[b]{2}{*}{ Parameters } & \multicolumn{4}{|c|}{ Author and Sampling Date } & \multirow[b]{2}{*}{$\begin{array}{l}\text { Maximum Permissible } \\
\text { Limit (EPA, 2003) }\end{array}$} \\
\hline & $\begin{array}{c}\text { Zinabu and Desta } \\
\text { (2002) } \\
\text { (Nov. 1995 to March 1996) }\end{array}$ & $\begin{array}{c}\text { Abay, } 2007 \\
\text { (Nov. } 2006 \text { to March 2007) }\end{array}$ & $\begin{array}{l}\text { Berehanu and Lemma } \\
\text { (2009) [20] } \\
\text { (May, 2008) }\end{array}$ & $\begin{array}{l}\text { Present Work } \\
\text { (Dec., 2009) }\end{array}$ & \\
\hline COD mg/l & - & 5183 & - & 400 & 150 \\
\hline DO mg/l & & & & 0.75 & NS \\
\hline $\mathrm{NO}_{3}^{-} \mathrm{mg} / \mathrm{l}$ & 31 & 17.8 & 8.7 & 5.3 & 50 \\
\hline $\mathrm{TN}$ mg/l & - & 353.8 & - & 40 & 40 \\
\hline $\mathrm{PO}_{4}^{3-} \quad \mathrm{mg} / \mathrm{l}$ & - & 9.04 & 7.3 & 386 & 10 \\
\hline $\mathrm{S}^{2-} \mathrm{mg} / \mathrm{l}$ & - & 1.7 & & 0.046 & 2.0 \\
\hline $\mathrm{SO}_{4}^{2-} \mathrm{mg} / \mathrm{l}$ & 56 & 136.3 & ND & 0.052 & 200 \\
\hline TDS mg/l & - & 3818.5 & 2626 & 1530 & 80 \\
\hline $\mathrm{EC}(\mu \mathrm{S} / \mathrm{cm})$ & - & 5455 & 3110 & 3030 & 1000 \\
\hline
\end{tabular}

${ }^{*}$ NS—not specified, ND—not detected.

Table 2. Mean values of some heavy metals $(\mu \mathrm{g} / \mathrm{l})$ measured in Hawassatextile effluent by various researches at different times.

\begin{tabular}{|c|c|c|c|c|c|}
\hline \multirow[b]{2}{*}{ Parameters } & \multicolumn{4}{|c|}{ Author and Sampling Date } & \multirow[b]{2}{*}{$\begin{array}{l}\text { Maximum Permissible } \\
\text { Limit (EPA, 2003) }\end{array}$} \\
\hline & $\begin{array}{c}\text { Zinabu and Pearce, } \\
2003 \\
\text { (Nov. 1995) }\end{array}$ & $\begin{array}{c}\text { Zinabu and Pearce, } \\
2003 \\
\text { (Mar. 1996) }\end{array}$ & $\begin{array}{c}\text { Abay, } 2007 \\
\text { (Nov. 2006 to March } \\
\text { 2007) }\end{array}$ & $\begin{array}{l}\text { Present Work } \\
\text { (Dec 10, 2009) }\end{array}$ & \\
\hline Co & 0.3 & ND & - & 10.7 & 1000 \\
\hline $\mathrm{Cr}$ & 17.7 & 22 & 120 & 2.3 & 1000 \\
\hline $\mathrm{Pb}$ & 0.4 & 2.4 & 160 & 28.1 & 500 \\
\hline $\mathrm{Cd}$ & 1.6 & ND & 30 & 0.12 & 1000 \\
\hline $\mathrm{Zn}$ & 8.9 & 163 & 40 & 41000.0 & 5000 \\
\hline $\mathrm{Fe}$ & 131.9 & ND & 1230 & 1500 & 1000 \\
\hline As & 10.6 & 9.4 & - & 0.69 & 250 \\
\hline $\mathrm{Hg}$ & 3.8 & ND & - & 0.32 & 1.0 \\
\hline
\end{tabular}

ND—not detected.

Textile effluent also contained a wide range of heavy metals (Table 2) which are mixed with dyes (Asamudo et al., 2005) [21]. Among heavy metals $\mathrm{Zn}$ and Fe of textile effluent were much higher (41 and 1.5 times higher, respectively) than the acceptable limits set by EPA (2003). Although not in the present result, Zinabu and Pearce (2003) [22] reported Hg content which was 3 times more than the acceptable limits in the discharge (Table 2).

Like physicochemical parameters, variation in concentrations of heavy metals have been noted among samples analyzed by different workers at different times and this could be attributed to rainfall that could dilute their concentrations in the oxidation ponds (Zinabu and Pearce, 2003). Moreover, the increase in concentrations of some of the metals with time in the effluents for the same sampling season could be attributed to the variation in composition depending on the processes used (Alemayehu, 2008).

\subsubsection{Effluent of Tabor Ceramics Factory}

The chemical parameters of ceramic effluent are shown in Table 3. Samples of ceramic effluent collected from 
Table 3. Chemical composition of Tabor ceramic effluent.

\begin{tabular}{|c|c|c|c|}
\hline \multirow{2}{*}{ Parameters } & \multicolumn{2}{|c|}{ Author and Sampling Date } & \multirow{2}{*}{$\begin{array}{l}\text { Maximum Permissible Limit in the } \\
\text { Effluent }\end{array}$} \\
\hline & $\begin{array}{l}\text { Berehanu and Lemma, } 2009 \\
\text { (May, 2008) }\end{array}$ & $\begin{array}{l}\text { Present work } \\
\text { (Dec 10, 2009) }\end{array}$ & \\
\hline COD & - & 100 & 250 \\
\hline DO mg/l & - & 3.64 & NS \\
\hline $\mathrm{NO}_{3}^{-} \mathrm{mg} / \mathrm{l}$ & 0.08 & 2.15 & 20 \\
\hline $\mathrm{NH}_{4}^{+} \quad \mathrm{mg} / \mathrm{l}$ & 0.34 & 0.11 & 5 \\
\hline TN mg/l & - & 11 & 80 \\
\hline $\mathrm{PO}_{4}^{3-} \quad \mathrm{mg} / \mathrm{l}$ & 0.08 & 245 & 10 \\
\hline $\mathrm{S}^{2-} \mathrm{mg} / \mathrm{l}$ & - & 3.35 & 2 \\
\hline $\mathrm{SO}_{4}^{2-} \quad \mathrm{mg} / \mathrm{l}$ & 271.7 & 2000 & 1000 \\
\hline TDS mg/l & 998 & 530 & 3000 \\
\hline $\mathrm{EC}(\mu \mathrm{S} / \mathrm{cm})$ & 1193 & 1059 & NS \\
\hline $\mathrm{Cd}$ mg/l & - & 0.00008 & 1.0 \\
\hline Co mg/l & - & 0.0112 & 1.0 \\
\hline $\mathrm{Cr} \mathrm{mg} / \mathrm{l}$ & - & 0.00123 & 2.0 \\
\hline Fe mg/l & - & 1.10 & 10 \\
\hline $\mathrm{Pb} \mathrm{mg} / \mathrm{l}$ & - & 0.042 & 0.5 \\
\hline Zn mg/l & - & 71.4 & 5 \\
\hline As mg/l & - & 0.00148 & 0.25 \\
\hline Hg mg/l & - & 0.00039 & 0.001 \\
\hline
\end{tabular}

*NS—not specified.

the ditch immediately after discharge to the environment contained high concentration of $\mathrm{PO}_{4}^{3-}$ (24.5 times), $\mathrm{S}^{2-}$ (1.7 times), $\mathrm{SO}_{4}^{2-}$ (2 times) and $\mathrm{Zn}$ (14 times) exceeding the provisional limit set by EPA (2003). The levels of nutrients were higher, especially $\mathrm{PO}_{4}^{3-}$, in the present investigation, but lower values was found in $\mathrm{Be}-$ rehanu and Lemma (2009) as indicated in Table 3. High nutrient concentrations can be inferred from huge growth of plants in the biological lagoon of ceramic factory (personal observation). Thus, the lower values in Berehanu and Lemma (2009) may have resulted from uptake by plant growing in the pond for a long time.

\subsubsection{Effluent of Soft Drinks Factory}

The chemical constituents of the effluent from soft drink factory are shown by Table 4. Among the measured parameters, high values of COD (1.6 times), $\mathrm{PO}_{4}^{3-}$ (20.5 times) and $\mathrm{Zn}$ (20.4 times) were found in the effluent than specified by EPA (2003) as the maximum permissible limit. The effluents from Soft Drinks Factory has not been studied, and therefore the results could not be compared.

In general, heavy metal concentrations of the textile factory effluent were higher than those of ceramic and soft drinks factories. Exceptions to this were high contents of Zn and Fe in the effluents of the soft drinks and ceramic factories, respectively. Sulphide and sulphate concentrations were very low in the textile effluents while high concentrations of sulphide and sulphate were found in ceramic effluents. Phosphate and total $\mathrm{N}$ concentrations in the textile effluent were also higher than in the other two sources. In general, the chemical composition of effluents of the factories differed from each other because their sources constitute different processes and use different chemicals and materials.

All the factories, whose effluents were studied, possess biological lagoons where they keep their effluents for some time before releasing it and microbial activity in the biological lagoons would have lowered the contents 
Table 4. Chemical parameters of Soft Drinks Factory from analysis in the present work.

\begin{tabular}{|c|c|c|}
\hline Parameters & $\begin{array}{c}\text { Present Work } \\
\text { (Dec 10, 2009) }\end{array}$ & Maximum Permissible Limit in the Effluent \\
\hline COD mg/l & 400 & 250 \\
\hline DO mg/l & 0.8 & NS \\
\hline $\mathrm{NO}_{3}^{-} \mathrm{mg} / \mathrm{l}$ & 1.05 & 20 \\
\hline $\mathrm{NH}_{4}^{+} \quad \mathrm{mg} / \mathrm{l}$ & ND & 5 \\
\hline $\mathrm{TN} \mathrm{mg} / \mathrm{l}$ & ND & 80 \\
\hline $\mathrm{PO}_{4}^{3-} \quad \mathrm{mg} / \mathrm{l}$ & 205 & 10 \\
\hline $\mathrm{S}^{2-} \mathrm{mg} / \mathrm{l}$ & 1.6 & 2 \\
\hline $\mathrm{SO}_{4}^{2-} \mathrm{mg} / \mathrm{l}$ & 47 & 1000 \\
\hline TDS mg/l & 876 & 3000 \\
\hline $\mathrm{EC}(\mu \mathrm{S} / \mathrm{cm})$ & 1699 & NS \\
\hline $\mathrm{Cd} \mathrm{mg} / \mathrm{l}$ & 0.00125 & 1.0 \\
\hline Co mg/l & 0.00625 & 1.0 \\
\hline Cr mg/l & 0.0298 & 2.0 \\
\hline Fe mg/l & 0.48 & 10 \\
\hline $\mathrm{Pb} \mathrm{mg} / \mathrm{l}$ & 0.0756 & 0.5 \\
\hline Zn mg/l & 102.1 & 5 \\
\hline As mg/l & 0.00177 & 0.25 \\
\hline Hg mg/l & 0.000135 & 0.001 \\
\hline
\end{tabular}

*NS—not specified, ND—not detected.

of at least the nutrients $\left(\mathrm{NO}_{3}, \mathrm{PO}_{4}\right.$, organic matter) $\mathrm{COD}$, BOD etc of the respective source effluent to acceptable levels. However, the measured physicochemical parameters of the effluents were determined from samples taken from the last treatment lagoon (outlet lagoon) and some parameters were higher than MPL. Therefore this could indicate that the biological treatment lagoons of these factories are not fully effective and it may also suggest that the effluents are potentially polluting.

\subsubsection{Effects of Factory Effluents on Survival of Tilapia Fry}

Fry mortality during the seven days of post treatment period considerably varied depending on the source of effluent and concentration levels used (Figure 2). Mortality at 1\% concentration level of textile effluent (16.1\%) was not far from that of the mortality in the control pond containing lake water alone (9.4\%). Whereas $5 \%, 10 \%$ and $20 \%$ concentration levels of the effluent killed significantly high proportion of the fry $(65 \%, 86.8 \%$ and 88.7\%, respectively). By contrast, fry mortality under ceramic and soft drink effluent treatments stayed nearly below $10 \%$, and they were not far off from the mortality of the control groups even at the higher concentration levels (10\% and 20\%) of the respective effluent trials (Figure 2).

Zinabu and Desta (2002) also reported a similar increasing trend of fry mortality based on experiments conducted on tilapia fry sampled from Lake Hawassa and reared in glass aquaria containing lake water treated with $10 \%$ and $20 \%$ of textile effluent. The two concentration levels killed on average $23 \%$ and $64 \%$ of the fry, respectively, and it occurred within 24 to 48 hours after exposure. Comparatively, higher mortalities were observed in the present trial at the two concentration levels and the difference could be due to the length of exposure time used in the two studies. Apparently, the findings of the present study as well as those of the mentioned authors strongly suggest that the effluent of textile factory had significant toxic effect on the fry that became more sever with increasing effluent concentration. Unlike this ceramic and soft drink effluents did not cause appreciable fry mortality more than that observed in the control ponds. 


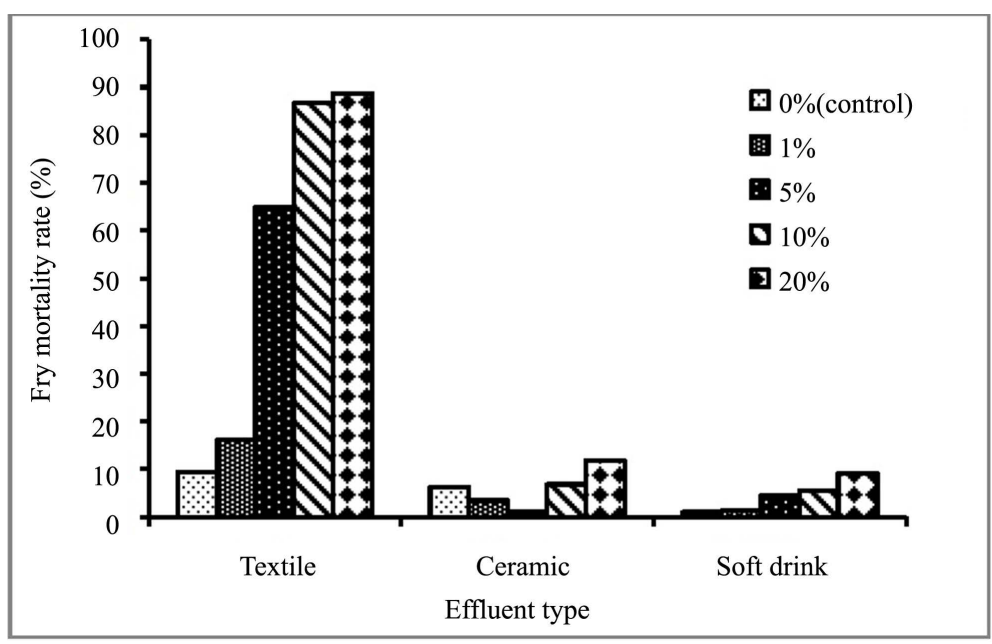

Figure 2. Tilapia fry, mortality rate after treatment with different concertration levels of the three factory effluents (textile, ceramic and soft drink factories).

Chemical analysis test done in the present study (Table 1) indicated that the effluent from textile factory has high conductivity $(3030 \mu \mathrm{S} / \mathrm{cm}$ ) which is more than threefold the conductivity of Lake Hawassa water i.e., 814 $\mu \mathrm{S} / \mathrm{cm}$. The tilapia of Lake Hawassa being a freshwater fish, it is adapted to live in waters with conductivities around $1000 \mu \mathrm{S} / \mathrm{cm}$ or below. Thus effluent having such a high conductivity, when mixed with the lake water at a considerable quantity, can elevate the conductivity of the pond water outside the normal range for the frays. In addition, the analysis showed that textile effluent had high COD (400 mg/l), very low dissolved oxygen (0.75 mg/l) (Table 1) and a high pH (12) (Zinabu and Desta, 2002). As a result, it can drastically lower oxygen saturation while increasing the alkalinity of the pond water outside the tolerable range for the fish. Tilapia inhabits the shallow depths $(1-5 \mathrm{~m})$ of the lake where the oxygen and $\mathrm{pH}$ of the water normally range between 6 to 10 (mg/l) and 7 - 9, respectively. A drop in oxygen level below 5 - $6 \mathrm{mg} / \mathrm{l}$ or a $\mathrm{pH}$ range outside the above indicated values can be critical for the fish.

Similarly, textile effluent contained high concentrations of toxic heavy metals and trace elements that are harmful for fish such as, $10.7 \mu \mathrm{g} / \mathrm{l}$ of cobalt, $28.1 \mu \mathrm{g} / \mathrm{l}$ of lead and $41.0 \mathrm{mg} / \mathrm{l}$ of zinc (Table 2). Zinabu and Desta (2002) also reported high contents of chromium $(42.6 \mu \mathrm{g} / \mathrm{l})$, arsenic $(43 \mu \mathrm{g} / \mathrm{l})$ and mercury $(5.1 \mu \mathrm{g} / \mathrm{l})$, although these were fairly low in the present chemical analysis. These authors also noted that the concentration of several toxic heavy metals in the effluent sampled from the biological lagoon (treated effluent) had considerably increased compared to the concentrations in the untreated effluent freshly released by the factory. This may indicate that the biological lagoons are not at all the solution to the problem of heavy metal content of the effluent.

\subsection{Effects of Factory Effluents on Algae Growth}

Algal biomass measured in terms of chlorophyll "a" concentration $(\mu \mathrm{g} / \mathrm{l})$ also varied with the kind of effluent and concentration level. Compared to the initial (first day) determination, chlorophyll "a" concentration measured on the $7^{\text {th }}$ day had increased by $51 \%, 48 \%, 74 \%, 27 \%$ and $31 \%$ at $0 \%, 1 \%, 5 \%, 10 \%$ and $20 \%$ concentration levels of textile effluent (Figure 3). These findings generally indicated that the $5 \%$ treatment level of textile effluent caused the highest rate of algal growth over and above the growth rate observed in the control pond containing lake water. On the other hand, algal growth at $1 \%$ concentration of the effluent was fairly similar to that observed in the control pond while the two higher concentrations (10\% and $20 \%)$ supported lower growth rates compared with the untreated lake water in the control pond.

Zinabu and Zerihun (2002) [23] also reported an enhanced rate of algal growth in lake water treated with 10 and $20 \%$ of textile effluent. According to them, the $10 \%$ treatment resulted in a higher algal growth rate compared to the $20 \%$ treatment, where as in the present case the maximum growth rate was observed at the $5 \%$ treatment. High concentrations of plant nutrients contained in the textile effluent, particularly phosphate (386 $\mathrm{mg} / \mathrm{l})$ and total nitrogen (40 mg/l) (Table 1) may have accounted to the observed excessive algal growth. On the 

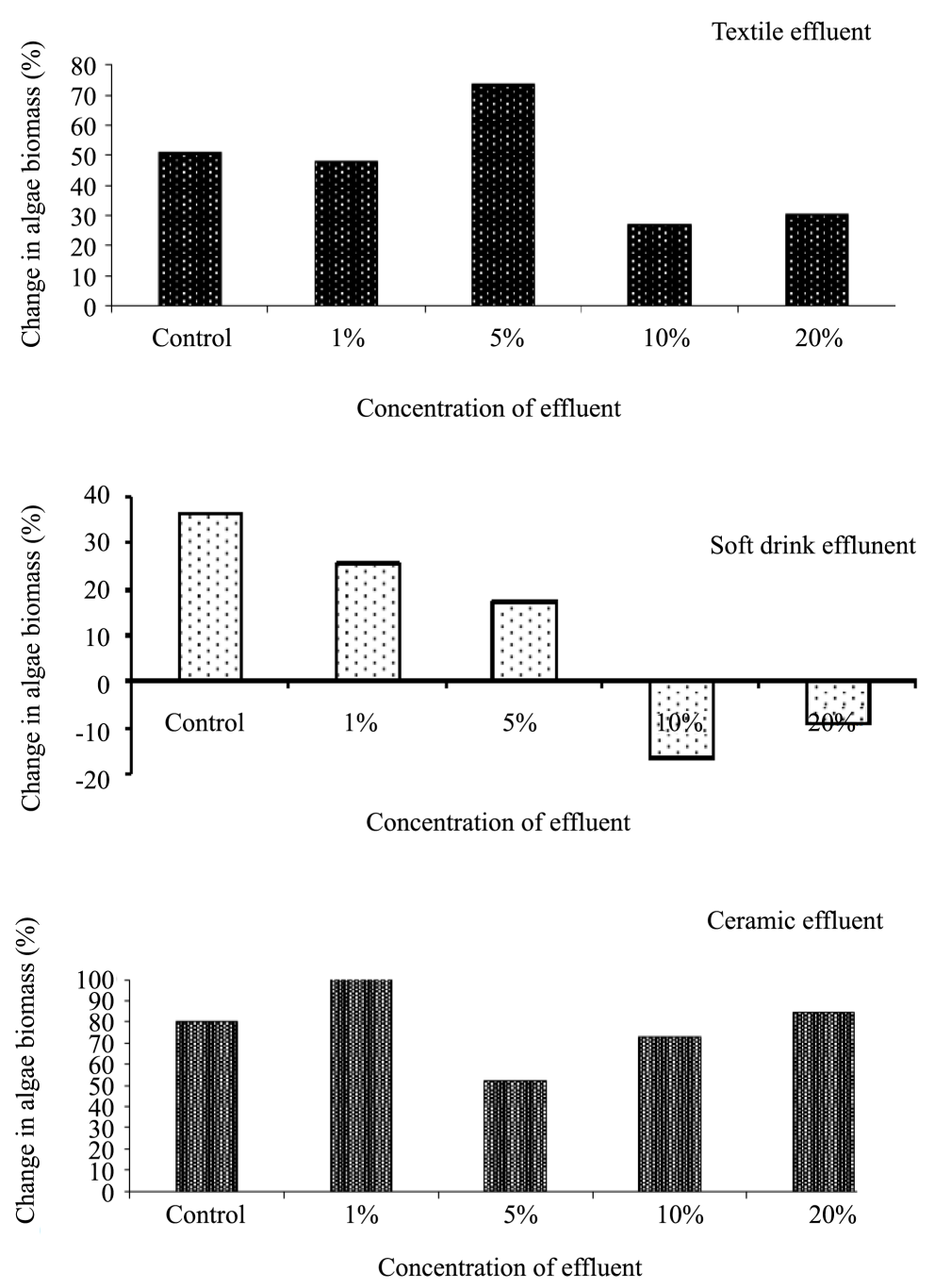

Figure 3. Growth rates if algae in lake water containing different concentration levels of the three factory effluents.

other hand, the reduction in the rate of algal growth with increasing concentration of the effluent may be explained by the toxic effects of the effluent when the concentration reaches a considerable level. The effluent may boost up algae growth at lower concentrations $(<10 \%)$ but at higher concentration levels, its toxic effect may become inhibitory than the growth rate achieved from nutrient enrichment. Nonetheless, the exact concentration level at which the effluent becomes inhibitory to the algae deserves future study.

Eutrophication, resulting from heavy nutrient loadings into water bodies, has direct effect on organisms in lakes as it boosts algal blooms leading to drastic drop of oxygen below threshold level for fish and other aquatic life. Mass fish kill caused by algal blooms due to excessive eutrophication is a common phenomenon in particular in small heavily polluted urban lakes. The growth of heterotrophic bacteria that decompose organic matter in lakes can also boost up when nutrients from domestic and industrial wastes enter the lakes. Such uncontrolled growth of bacteria depletes oxygen from the water and the resulting anoxic condition force the bacteria to revert to anaerobic respiration. The later process releases various undesirable by products such as ammonia, sulfur dioxide etc that are toxic to aquatic life.

Considering the effluent of soft drink factory, algal growth progressively diminished with increasing concentration of the effluent (Figure 3). The overall change (between initial—day 7) in chlorophyll "a" concentration was highest in the control pond (36.2\%) and decreased at $1 \%$ and $5 \%$ levels (21.7\% and $17.4 \%$, respectively), while the $10 \%$ and $20 \%$ concentrations resulted in a fall in final biomass compared to the initial $(-17 \%$ and 
$-9.4 \%$, respectively). In view of the relatively high contents of phosphate $(205 \mathrm{mg} / \mathrm{l})$ in the soft drink effluent (Table 4), nutrient deprivation may not be the reason for its inhibitory effect on the algae particularly at higher concentrations.

The effluent from soft drink factory is dark brown in color and has considerable amount of TDS (876 mg/l) and COD (400 mg/l) (Table 4) suggesting the presence of high dissolved organic matter. In the presence of the latter, heterotrophic bacteria that decompose organic matter are benefited and out compete autotrophic algae for nutrients. Thus this suppresses algal growth as seen from the low biomass of algae at the higher concentration treatments of the effluent. However the inhibitory effect should not be considered as a positive outcome because either boosting or inhibiting algal growth is undesirable for a healthy lake ecosystem.

Contrary to the two mentioned effluent treatments, percent increase in chlorophyll "a" concentration in ponds treated with ceramic effluent were fairly comparable to the observed increase in the control pond (Figure 3). The overall change at $0 \%, 1 \%, 5 \% 10 \%$ and $20 \%$ concentration treatments were $80.1 \%, 111.9 \%, 51.9 \%, 72.8 \%$ and $84.7 \%$, respectively. Thus, ceramic effluent did not have abnormal influence on algal growth and this may be related to the relatively low level of nutrients it contained (Table 3).

\section{Conclusion}

Results of the analysis on the chemical composition of effluents from different sources with respect to the provisional discharge limit in general, show that several parameters in the effluent are well above the limit. This indicates the treatments lagoons of the respective effluent sources are not fully effective in removing or reducing biodegradable pollutants to the desired level. The pond experiments also strongly suggest that the effluent from textile factory is potentially hazardous to the survival of fish. Although the soft drink effluent contained high amount of nutrients to cause eutrophication problem in the lake, the effluents had inhibitory effects on algal growth from other constituents in the effluent even at lower concentration. The effluent of ceramic did not cause appreciable problem on algal growth as well as fish survival. This study suggests that effluent nutrient concentration alone cannot be used as a predictive tool for causing eutrophication in a water body.

\section{Acknowledgements}

SOS Sahel Ethiopia is thanked for financial support for this study. The authors deeply appreciate the factories for allowing effluent sampling. We also appreciate Hawassa University, College of Agriculture for allowing us to use the ponds for our experiment. Wondo Genet College of Forestry and Natural Resources and Ethiopian Health and Nutrition Research Institute are also thanked for their support in the chemical analysis of water samples.

\section{References}

[1] Tudorancea, C., Baxter, R.M. and Fernando, C.H. (1989) A Comparative Limnological Study of Zoobenthic Associations in Lakes of the Ethiopian Rift Valley. Archives of Hydrobiologia/Supplement, 83, 121-174.

[2] Seyoum M. and Fernando, C.H. (1991) Seasonality and Abundance of Some Dominant Crustacean Zooplankton in LakeHawassa, a Tropical Rift Valley Lake in Ethiopia. Hydrobiologia, 226, 137-152. http://dx.doi.org/10.1007/BF00006856

[3] Kebede, E. (1987) A Seasonal Study on the Species Composition of and Phytoplankton Biomass in Lake Hawassa, Ethiopia. MSc Thesis, Addis Ababa University, Addis Ababa, 70 p.

[4] Dessie, G. and Kleman, J. (2007) Pattern and Magnitude of Deforestation in the South Central Rift Valley Region of Ethiopia. Mountain Research and Development, 27, 162-168. http://dx.doi.org/10.1659/mrd.0730

[5] Zinabu, G.M. and Desta, Z. (2002) The Chemical Composition of the Effluent from Hawassa Textile Factory and Its Effects on Aquatic Biota. SINET: Ethiopian Journal of Science, 25, 263-274.

[6] Tenalem, A. (2007) Water Management Problems in the Ethiopian Rift: Challenges for Development. Journal of African Earth Sciences, 48, 222-236.

[7] Kebede, E. and Belay, A. (1994) Species Composition and Phytoplankton Biomass in a Tropical African Lake (Lake Hawassa, Ethiopia). Hydrobiologia, 288, 13-32. http://dx.doi.org/10.1007/BF00006802

[8] Zinabu, G.-M. and Pearce, N.J.G. (2003) Concentrations of Heavy Metals and Related Trace Elements in Some Ethiopian Rift Valley Lakes and Their Inflows. Hydrobiologia, 429, 171-178. 
[9] Zinabu, G.-M. (2002) The Effect of Wet and Dry Seasons on Concentrations of Solutes and Phytoplankton Biomass in Seven Ethiopian Rift Valley Lakes. Limnologica, 32, 169-179. http://dx.doi.org/10.1016/S0075-9511(02)80006-8

[10] Ataro, A., Wondimu, T. and Chandravanshi, B.S. (2003) Trace Metals in Selected Fish Species from Lakes Hawassa and Ziway, Ethiopia. SINET: Ethiopian Journal of Science, 26, 103-114.

[11] Tekle-Giorgis, Y. (2002) Comparative Age and Growth Assessment of the African Catfish, Clarias gariepinus Burchell (Clariidae) and, Nile Perch, Latesniloticus, Linn (Centropomidae) in the Three Southern Rift Valley Lakes of Ethiopia (Lakes Awassa, Abaya and Chamo). PhD Thesis, Addis Ababa University, Addis Ababa, 160.

[12] Talling, J.F. and Driver, D. (1963) Some Problems in the Estimation of Chlorophyll-a in Phytoplankton. Proceedings of the Conference of Primary Productivity Measurement, Marine and Freshwater, University of Hawaii, Honolulu, Atomic Energy Commission TID-7633, 142-146.

[13] Abay, B. (2007) Assessment of Downstream Profiles of Hawassa Textile Effluent along Tikur Wuha River Using Physico-Chemical and Macro Invertebrate Indicators. MSc Thesis, Addis Ababa University, Addis Ababa, 67.

[14] Desta, Z. (1997) Industrial Environmental Management: The Case of Hawassa Textile. MSc Thesis, Wageningen Agricultural University, Wageningen, 95.

[15] Alemayehu, T. (2008) Environmental Resources and Recent Impacts in the Hawassa Collapsed Caldera, Main Ethiopian Rift. Quaternary International, 189, 152-162. http://dx.doi.org/10.1016/j.quaint.2007.10.006

[16] Pala, A. (2001) Chemical Treatment of Textile Wastewaters: Statistical Characterization, Colour and Sulfide Removal. Indian Journal of Environmental, 43, 128-134.

[17] Wynne, G., Maharaj, D. and Buckley, C. (2001) Cleaner Production in the Textile Industry-Lessons from the Danish Experience, School of Chemical Engineering, University of Natal, Durban, 3.

[18] Mathur, N., Bhatnagar, P. and Bakre, P. (2005) Assessing Mutageni City of Textile Dyes from Pali (Rajasthan) Using Ames Bioassay. Applied Ecology and Environmental Research, 4, 111-118. http://dx.doi.org/10.15666/aeer/0401_111118

[19] Yusuff, R.O. and Sonibare, J.A. (2004) Characterization of Textile Industries' Effluents in Kaduna, Nigeria and Pollution Implications. Global Nest Journal, 6, 211-220.

[20] Berehanu, B. and Lemma, B. (2009) Evaluation of the Ground Water Quality for Drinking and Other Domestic Purpose in Hawassa Town. Research Report. Hawassa University, Wondo Genet College of Forestry and Natural Resources, Hawassa.

[21] Asamudo, N.U., Daba, A.S. and Ezeronye, O.U. (2005) Bioremediation of Textile Effluent Using Phanerochaete chrysosporium. African Journal of Biotechnology, 4, 1548-1553.

[22] Zinabu, G.M., Pearce, N.J.G. and Ahlgren, I. (2004) Toxic Metals and Related Trace Elements in Some Ethiopian Hot Springs. Ethiopian Jouranal of Biological Sciences, 3, 69-80.

Kebede, E., Zinabu, G.M. and Ahlgren, I. (1994) The Ethiopian Rift Valley Lakes: Chemical Characteristics of a Salinity-Alkaline Series. Hydrobiologia, 288, 1-12.

[23] Gebre-Mariam, Z. and Desta, Z. (2002) The Chemical Composition of the Effluent from Hawassa Textile Factory and Its Effects on Aquatic Biota. SINET: Ethiopian Journal of Science, 25, 263-274. 